\title{
Induction of Extracellular Polygalacturonase and Its mRNA in the Phytopathogenic Fungus Fusarium moniliforme
}

\author{
By G. DE LORENZO, G. SALVI, L. DEGRÀ, R. D'OVIDIO AND \\ F. CER VONE* \\ Dipartimento di Biologia Vegetale, Universita' di Roma 'La Sapienza', Piazzale Aldo Moro, \\ 00100 Roma, Italy
}

(Received 21 January 1987; revised 28 May 1987)

\begin{abstract}
The activity of extracellular polygalacturonase (PG) was strongly induced in Fusarium moniliforme by growing the fungus in a minimal medium containing pectin as sole carbon source. PG was the major protein component of the extracellular fluid whereas no detectable PG activity was found in culture filtrates of the fungus grown in a medium containing glucose as carbon source. $F$. moniliforme PG was purified to homogeneity by a procedure involving ammonium sulphate precipitation, carboxymethyl cellulose chromatography and preparative isoelectric focusing. The purified protein showed one protein band in non-denaturating PAGE and two major bands (molecular mass 41.5 and $45.0 \mathrm{kDa}$ ) plus two minor bands $(38.0$ and $48.5 \mathrm{kDa}$ ) in SDS-PAGE. The bands consisted of glycosylated polypeptide chains. Poly(A)containing RNA, purified from total RNA extracted from $F$. moniliforme grown in PG-inducing conditions and translated in vitro in a reticulocyte cell-free translation system, produced two polypeptide chains $(47$ and $51 \mathrm{kDa}$ ) which were not present in the translation products of the non-induced poly(A)-containing RNA. The two polypeptide chains were immunoprecipitated with an $\operatorname{IgG}$ against $F$. moniliforme homogeneous PG.
\end{abstract}

\section{INTRODUCTION}

The importance of polygalacturonase (PG; EC 3.2.1.15) in pathogenesis is now well established for certain plant diseases characterized by a rapid and extensive degradation of cell wall, increase in permeability and death of protoplasts (Bateman \& Basham, 1976). The role of PG, although less important, is also acknowledged for diseases, mainly caused by biotrophs, where only a minimal breakdown of cell wall occurs during penetration and colonization by an infecting fungus (Cooper, 1984). Of the many polysaccharide-degrading enzymes, PG must act before other enzymes can attack other substrates (Karr \& Albersheim, 1970), and it is the first polysaccharide-degrading enzyme secreted by certain pathogens cultured on isolated cell walls (Jones et al., 1972). Moreover, the enzyme is able to activate the plant defence responses by releasing cell wall fragments which induce the synthesis of phytoalexins (Bruce \& West, 1982; Walker-Simmons et al., 1983).

In most pathogens the synthesis of $P G$ is regulated. A strong induction of enzyme activity is usually obtained when phytopathogenic fungi are cultivated in media containing pectic substances as carbon source (Cervone et al., 1986). However, the molecular mechanism of PG induction is still unclear and the regulation of its synthesis needs to be investigated in more detail. This paper reports the isolation of PG and translatable PG-mRNA in the fungus Fusarium moniliforme.

Abbreviations: PG, polygalacturonase; CMC, carboxymethyl cellulose; HRP, horse-radish peroxidase; r.v.u., relative viscosimetric unit; r.g.u., activity (reducing group) unit. 


\section{METHODS}

Chemicals. Sodium polypectate and $\alpha$-D-galacturonic acid were obtained from NBC. Citrus pectin was from Sigma: dinitrosalicylic acid and thiobarbituric acid were from Merck; carboxymethyl cellulose (CMC) CM-52 was from Whatman; ampholine carriers and oligo(dT)-cellulose were from Pharmacia; SDS, acrylamide and $N^{\prime}, N$-methylene-bis-acrylamide were from Bio-Rad. L-[ ${ }^{35}$ S $]$ Methionine and EN ${ }^{3}$ HANCE were obtained from Amersham. Adenosine vanadyl sulphate and rabbit reticulocyte lysate were from BRL. Pansorbin (Staphylococcus aureus cells bearing protein A), obtained from Calbiochem, was heated at $85^{\circ} \mathrm{C}$ for 30 min and washed with SDS and Triton X-100 before use according to Chin et al. (1982). Goat antirabbit IgG conjugated with horse-radish peroxidase (HRP) was from Miles. All other chemicals were reagent grade.

Fungal culture. Fusarium moniliforme strain FC-10, from the collection of F. Cervone, was grown on V8 agar $\left(20^{\circ}\right.$; v/v, V8 vegetable juice; Campbell) at $25^{\circ} \mathrm{C}$. Spores $\left(10^{5}\right)$ collected with $1-2 \mathrm{ml}$ sterile water from a fully invaded Petri dish were inoculated into a $250 \mathrm{ml}$ flask containing $100 \mathrm{ml}$ liquid Czapek-Dox broth medium and incubated in a rotary shaker $\left(100\right.$ r.p.m.) at $25^{\circ} \mathrm{C}$ for $4 \mathrm{~d}$. Samples $(5 \mathrm{ml})$ were then used to inoculate 12 flasks each containing $100 \mathrm{ml}$ Czapek-Dox broth, which were incubated as before for $4 \mathrm{~d}$. Mycelium of each flask was collected, in sterile conditions, by centrifugation at $12000 \mathrm{~g}$ for $30 \mathrm{~min}$ and was used to inoculate a $500 \mathrm{ml}$ flask (12 flasks in total) containing $200 \mathrm{ml}$ Czapek--Dox broth medium to which $1 \%(\mathrm{w} / \mathrm{v})$ pectin had been added. The cultures were incubated at $25^{\circ} \mathrm{C}$ without shaking.

Enzyme assay. PG activity was determined by measuring the decrease in relative viscosity of a $0.6 \%(\mathrm{w} / \mathrm{v})$ solution of sodium polypectate as reported by Cervone et al. (1977). One relative viscosimetric unit (r.v.u.) was defined as the amount of enzyme causing a $50 \%$ reduction in the viscosity of $6 \mathrm{ml}$ of the reaction mixture in $1 \mathrm{~min}$ under the conditions of the assay. Hydrolysis of glycosidic bonds was followed by reducing end-groups analysis, either by using the dinitrosalicylic acid procedure (Miller, 1959) or the Somogyi (1952) assay with Nelson's arsenomolybdate reagent (Nelson, 1944). One activity unit (r.g.u.) was defined as the amount of enzyme producing 1 microequivalent of reducing groups $\mathrm{min}^{-1}$. The enzyme products were examined by paper chromatography as reported by Nasuno \& Starr (1966).

Purification of PG. PG was purified to homogeneity by a modification of the method reported by Cervone $e t$ al. (1977). Pectin-induced filtrate (21) from 4-d-old cultures of $F$. moniliforme was centrifuged at $10000 \mathrm{~g}$ for $20 \mathrm{~min}$ and the supernatant was saturated with ammonium sulphate. The precipitated proteins were collected by centrifugation at $15000 \mathrm{~g}$ for $30 \mathrm{~min}$, resuspended in $50 \mathrm{ml}$ distilled water and dialysed against two changes of $20 \mathrm{~mm}$-sodium acetate buffer, pH 5.0. The enzyme solution was then adsorbed on a $2.5 \times 30 \mathrm{~cm} \mathrm{CMC} \mathrm{column}$ equilibrated with $20 \mathrm{~mm}$-acetate buffer, pH $5 \cdot 0$, and eluted at $4{ }^{\circ} \mathrm{C}$ with $100 \mathrm{ml}$ of the same buffer followed by $400 \mathrm{ml}$ of a linear $0-0.4 \mathrm{M}-\mathrm{NaCl}$ gradient in acetate buffer. The fractions with the highest specific activity were pooled, dialysed at $4{ }^{\circ} \mathrm{C}$ against $0.5 \%$ glycine and subjected to isoelectric focusing. The fractions containing PG activity were pooled, saturated with ammonium sulphate and centrifuged at $15000 \mathrm{~g}$ for $30 \mathrm{~min}$. The enzyme was then resuspended in $5 \mathrm{ml}$ distilled water and stored at $-20^{\circ} \mathrm{C}$ until required. No loss of activity was detected after 1 month of storage.

Isoelectric focusing, PAGE and protein determination. Isoelectric focusing was done at $4{ }^{\circ} \mathrm{C}$ as reported by Cervone et al. (1977).

SDS-PAGE was done in $9 \cdot 25 \%(w / v)$ acrylamide slab gels prepared according to Studier (1973). Gels were stained for proteins with silver nitrate according to Andrews (1981) and for glycoproteins according to Zacharius et al. (1969). Molecular mass standards ( $\mathrm{kDa})$ were phosphorylase b $(92.5)$, bovine serum albumin $(66 \cdot 2)$, ovalbumin (45.0), carbonic anhydrase (31.0) and soybean trypsin inhibitor (21.5).

Protein concentration was measured according to the method of Lowry using bovine serum albumin as a standard.

Immunology: Two New Zealand White rabbits were injected subcutaneously with $1 \mathrm{mg} F$. moniliforme homogeneous PG dissolved in $3 \mathrm{ml}$ Freund's complete adjuvant. An additional injection was made $15 \mathrm{~d}$ later and bleeding was done 1 month after the first injection. IgG reacting with PG were purified by passing $10 \mathrm{ml}$ antiserum through a column containing a PG-Sepharose conjugate prepared by immobilizing $4 \mathrm{mg} P G$ to $C N B r-$ activated Sepharose $4 B$ according to Eveleigh \& Levy (1977). Purified IgG reacted with homogeneous PG in double immunodiffusion tests done according to Ouchterlony (1962). Both antiserum and purified IgG exhibited a complete inhibitory effect when incubated with the homogeneous PG.

For immunoblotting experiments the proteins, after PAGE, were electrophoretically transferred to nitrocellulose according to Towbin et al. (1979). The purified IgG were used as a probe at a concentration of $0.15 \mu \mathrm{g} \mathrm{m}^{-1}$. Goat antirabbit IgG conjugated to HRP diluted 1:2000 were used as a second antibody. For the HRP colour development the blot was soaked in a solution prepared by adding $30 \mathrm{mg} 4$-chloro-1-naphthol dissolved in $10 \mathrm{ml}$ cold methanol to $50 \mathrm{ml} 10 \mathrm{~mm}$-Tris/ $\mathrm{HCl}$, pH 7.5 , containing $0.9 \% \mathrm{NaCl}$ and $0.02 \% \mathrm{H}_{2} \mathrm{O}_{2}$.

$m R N A$ isolation. Two days after initiating induction of $\mathrm{PG}$, mycelia were harvested by filtration through Whatman no. 1 paper. The mycelial mat was washed extensively with distilled water, filtered until dry, and ground to a fine powder in a Waring blender with liquid nitrogen. The powder from $50 \mathrm{~g}$ wet mycelium was suspended in 
$250 \mathrm{ml}$ cold $100 \mathrm{~mm}-\mathrm{Tris} / \mathrm{HCl}$ buffer, $\mathrm{pH} 7 \cdot 5$, containing $50 \mathrm{~mm}-\mathrm{NaCl}, 0 \cdot 5 \% \mathrm{SDS}$ and $10 \mathrm{~mm}$-adenosine vanadyl sulphate. The suspension was extracted with 1 vol. phenol/chloroform/isoamyl alcohol $(24: 24: 1$, by vol.) and centrifuged at $10000 \mathrm{~g}$ for $15 \mathrm{~min}$. The aqueous phase was brought to $0.3 \mathrm{M}$ in sodium acetate, and nucleic acids were precipitated overnight at $-20^{\circ} \mathrm{C}$ with 2.5 vols cold ethanol. The pellet was washed four times with cold $2 \mathrm{M}$ $\mathrm{LiCl}$, twice with $95 \%(\mathrm{v} / \mathrm{v})$ ethanol containing $100 \mathrm{~mm}$-sodium acetate and, finally, with cold $95 \%$ ethanol. The pellet was then dried under vacuum and resuspended in $30 \mathrm{ml}$ cold $100 \mathrm{~mm}$-Tris/ $\mathrm{HCl}$ buffer, $\mathrm{pH} \mathrm{7.5}$. The solution was extracted with 1 vol. cold phenol pre-saturated with $100 \mathrm{~mm}$-Tris and then with 1 vol. of chloroform/isoamyl alcohol $(24: 1, v / v)$. The aqueous phase was precipitated in the presence of sodium acetate as described above and centrifuged for $20 \mathrm{~min}$ at $8000 \mathrm{~g}$ at $4{ }^{\circ} \mathrm{C}$. The pellet was resuspended in $50 \mathrm{ml} 100 \mathrm{mM}-\mathrm{Tris} / \mathrm{HCl}, \mathrm{pH} 7 \cdot 5$. The solution was centrifuged for $15 \mathrm{~min}$ at $15000 \mathrm{~g}$ in order to sediment contaminating polysaccharides. The nucleic acids were finally precipitated by sodium acetate and cold ethanol, collected by centrifugation and resuspended in 1-2 $\mathrm{ml}$ sterile water. From the RNA preparation, poly(A)-containing mRNA was isolated by three passages through an oligo(dT)-cellulose column. Poly(A)-containing mRNA was precipitated with 2 vols cold ethanol. The precipitate, collected by centrifugation and dried under vacuum, was dissolved in sterile distilled water and stored at $-20^{\circ} \mathrm{C}$ in small portions. RNA content was calculated by assuming that one $A_{260}$ unit was equivalent to $50 \mu \mathrm{g}$ RNA ml ${ }^{-1}$. A typical yield of about $400 \mu \mathrm{g}$ RNA was obtained from $50 \mathrm{~g}$ wet mycelium. The $A_{260} / A_{280}$ ratio of the isolated RNA was greater than 1.9 .

In vitro protein synthesis. Purified poly(A)-containing mRNA was translated in a rabbit reticulocyte lysate system using $\left[{ }^{35}\right.$ S]methionine according to the manufacturer's (BRL) directions. The reaction mixture contained $5-10 \mu \mathrm{g}$ added RNA in a total volume of $30 \mu \mathrm{l}$. Incorporation of $\left.{ }^{35} \mathrm{~S}\right]$ methionine into proteins was checked by spotting $1 \mu \mathrm{l}$ samples of the reaction mixture on Whatman no. 1 filter paper and boiling for $10 \mathrm{~min}$ in $10 \%(\mathrm{w} / \mathrm{v})$ TCA. The filter paper was washed and assayed for radioactivity according to the BRL instructions. Translation products were separated by electrophoresis in SDS-PAGE slab gels $(7.5 \%, \mathrm{w} / \mathrm{v}$, acrylamide) and detected by fluorography.

Immunoprecipitation of in vitro translation products. Translation products were immunoprecipitated from the rabbit reticulocyte lysate using rabbit anti-PG IgG. The lysate was incubated overnight at $4{ }^{\circ} \mathrm{C}$ with anti-PG IgG. Pansorbin (Kessler, 1981) was added, the solution was mixed for a further $2 \mathrm{~h}$ and the bound antibody-protein-A complex was collected by centrifugation. Immunoprecipitated samples were analysed by SDS-PAGE and visualized by fluorography as reported above.

\section{RESULTS}

\section{Production and purification of $P G$}

When $F$. moniliforme was grown on minimal medium containing glucose as carbon source no extracellular PG could be detected. Transfer of the mycelium into a pectin-containing medium caused a rapid induction of enzyme activity, which reached a maximum on the third day after transfer (Fig. 1). After $3 \mathrm{~d}$ of growth in pectin medium, PG was the major protein component $\left(>80 \%, 10 \mathrm{mg} \mathrm{l}^{-1}\right)$ of the culture filtrate. No enzyme was detected in the non-induced culture filtrate, although a faint band of approximately $44 \mathrm{kDa}$ was visible. This band, however did not show any immunological reaction with anti-PG IgG (Fig. 2).

The elution profile (CMC column chromatography) of PG from 21 of $F$. moniliforme culture filtrate is shown in Fig. $3(a)$. A single peak of PG activity eluted at about $0.2 \mathrm{M}-\mathrm{NaCl}$. The fractions with the highest specific PG activity were subjected to isoelectric focusing. One distinct peak was focused at $\mathrm{pI} 6 \cdot 7 \pm 0 \cdot 1$. The accuracy of the $\mathrm{pI}$ value is given as the difference between the highest and lowest figure from six experiments (Fig. $3 b$ ). The fractions containing PG activity were precipitated with ammonium sulphate and resuspended in $5 \mathrm{ml}$ distilled water. The enzyme was then subjected to gel filtration through a $1.5 \times 60 \mathrm{~cm}$ Sephadex G-50 column equilibrated with distilled water. The $\mathrm{PG}$ activity eluted as a single peak coinciding with the maximum $A_{280}$, about $30 \mathrm{ml}$ after the front of the column (Fig. $3 c$ ).

\section{Characterization of $P G$}

The purified PG hydrolysed the glycosidic bonds of the substrate in a typical 'endo' fashion. A low rate of reducing-group increase corresponded to an high rate of viscosity decrease during the enzymic breakdown of the substrate (Fig. 4). This was confirmed by analysing products of hydrolysis by paper chromatography. The length of oligogalacturonates produced decreased during the course of enzyme hydrolysis, reaching mono- and digalacturonate as final products 


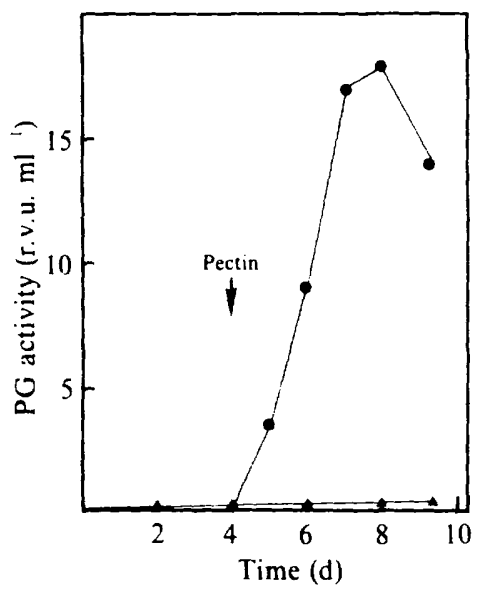

Fig. 1. Time-course of $P G$ induction by pectin in glucose-grown $F$. moniliforme. After $4 \mathrm{~d}$ of growth in glucose, the mycelium was transferred to a pectin-containing medium. The mycelium was harvested $2 \mathrm{~d}$ later and mRNA was isolated. Other experimental conditions are described in the text. Pectininduced; $\boldsymbol{\Delta}$, non-induced.

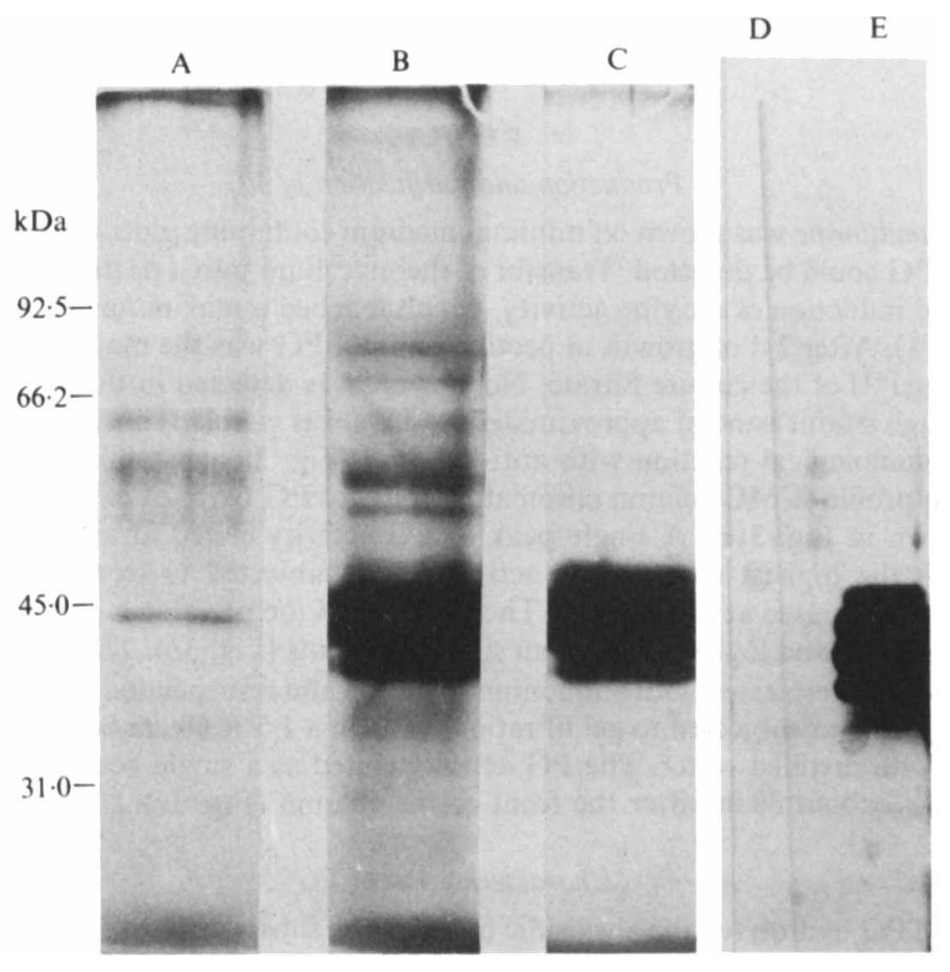

Fig. 2. SDS-PAGE (lanes A, B and C) and Western blots (lanes D and E) of $50 \mu 1$ of glucose-grown (A, D) and pectin-grown (B, E) F. moniliforme culture filtrate. Lane C, $1 \mu$ l of PG purified as described in Fig. 3 legend. Proteins in lanes A, B and C were stained with silver nitrate. Wells were deliberately overloaded to allow minor bands to be detected. 


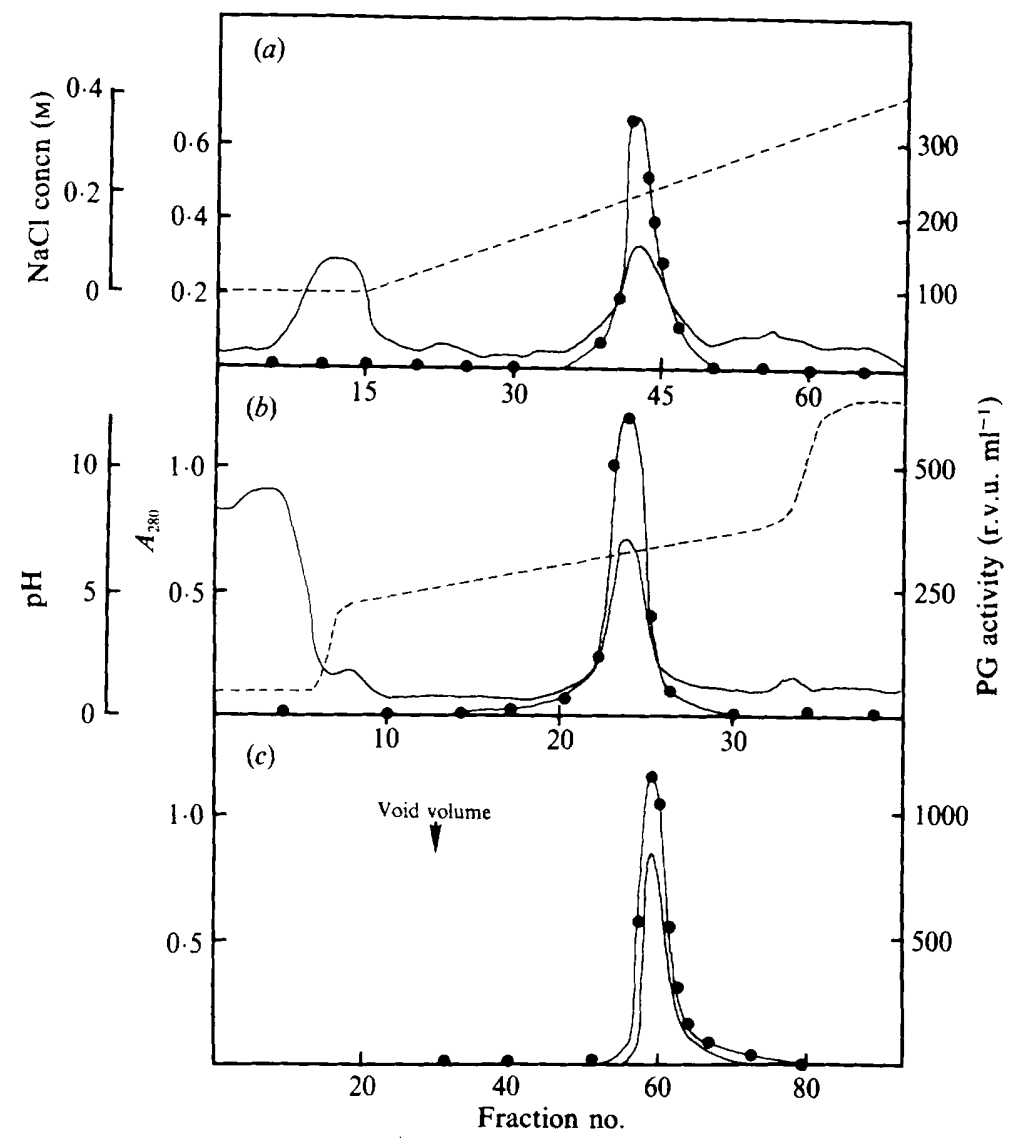

Fig. 3. Purification of F. moniliforme PG., $\mathrm{PG}$ activity; - $-A_{280}$. (a) Elution profile of PG activity from a CMC column. Fractions $(7 \mathrm{ml})$ were collected and analysed. -- , $\mathrm{NaCl}$ gradient. (b) Isoelectric focusing of PG. Fractions $(2.5 \mathrm{ml})$ were collected and analysed. ---, $\mathrm{pH}$ gradient. (c) Elution profile of PG from a Sephadex G-50 column. Fractions $(1 \mathrm{ml})$ were collected and analysed.

(Fig. 5). Purified PG had a specific activity of 1170 r.v.u. $\mathrm{ml}^{-1}$ and 430 r.g.u. $\mathrm{ml}^{-1}$ and showed only one diffuse band on PAGE (Fig. 6, lane B). Nevertheless, in denaturating conditions (SDSPAGE) the enzyme was resolved into four polypeptide chains with molecular masses of $38,41 \cdot 5$, 45 and $48.5 \mathrm{kDa}$ (Fig. 6, lane C). The polypeptide chains were positively stained by Schiff's reagent, showing them to be glycoproteins (Fig. 6, lane D). All four polypeptide chains strongly reacted with Aspergillus niger anti-PG IgG (Fig. 6, lane E). Since A. niger PG consists of a single polypeptide chain (Cervone et al., 1986) and a homogeneous enzyme was used for preparing antibodies, it is likely that the four bands represent different forms of $F$. moniliforme PG.

\section{Poly $(A)$-containing $m R N A$ isolation and in vitro translation}

Poly(A)-containing mRNA from induced and non-induced cultures of $F$. moniliforme was extracted and purified as reported in Methods. In a cell-free system RNA from both cultures translated at comparable rates. No PG activity was detected in the in vitro translation products. However, when the total translation products were examined by SDS-PAGE the patterns observed with induced and non-induced cultures were very similar, except for two protein bands of 47 and $51 \mathrm{kDa}$ which were present only in the translation products of $\mathrm{mRNA}$ from induced cultures (Fig. 7, lanes A and B). 


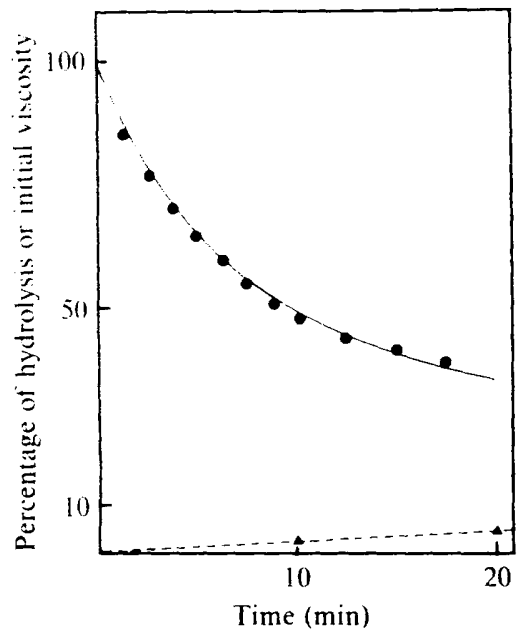

Fig. 4

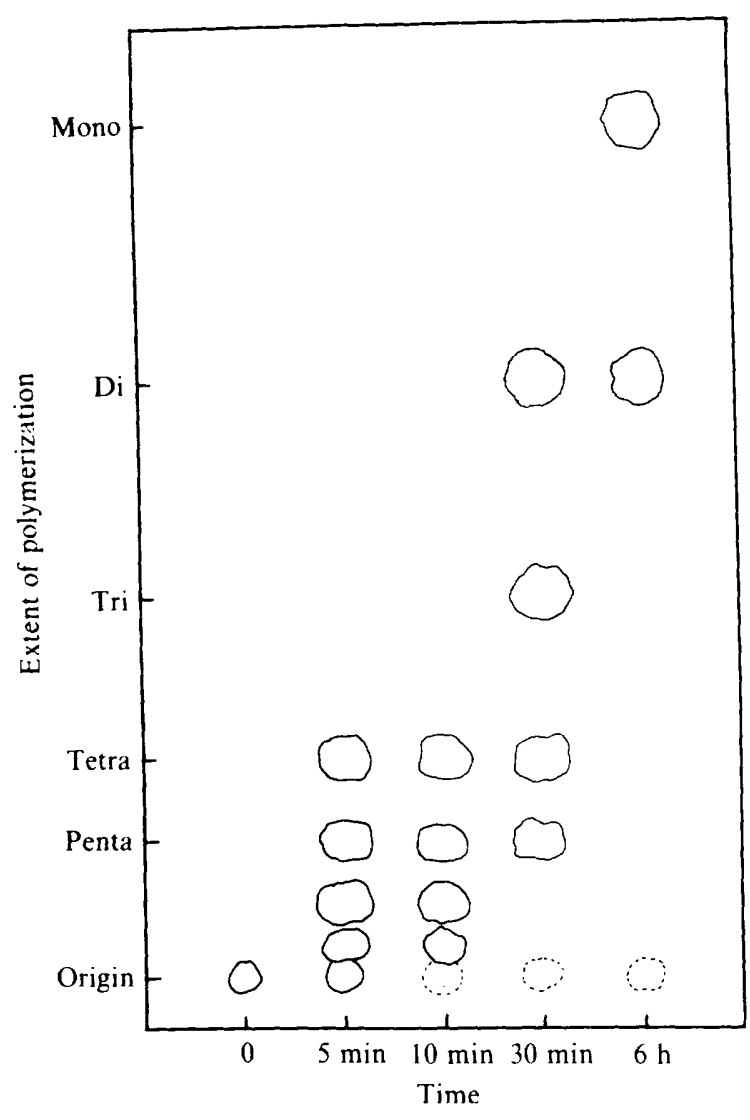

Fig. 5

Fig. 4. Viscosity changes (O) and percentage of hydrolysis $(\mathbf{A})$ of sodium polypectate by $P G$ as a function of time. Homogeneous enzyme (0.1 r.v.u.) was used.

Fig. 5. Paper chromatogram of the reaction products of homogeneous PG with sodium polypectate. The incubation mixture $(1 \mathrm{ml})$ contained $0.5 \%$ sodium polypectate, 50 mm-sodium acetate buffer, pH 5.0, and PG (10 r.v.u.). Samples $(25 \mu \mathrm{l})$ from the reaction mixture were boiled for $5 \mathrm{~min}$ and spotted on the chromatogram at the indicated times.

Translation products of induced and non-induced mRNAs were immunoprecipitated with anti-PG IgG and analysed by SDS-PAGE. Protein bands at 47 and $51 \mathrm{kDa}$ were clearly detected by fluorography showing that poly(A)-containing mRNA obtained from induced cultures but not that from non-induced cultures contained mRNA for PG (Fig. 7, lane C). PG added to the translation mixture before addition of the antibody effectively competed with the 47 and $51 \mathrm{kDa}$ translation products, strongly suggesting that these products are immunologically similar to mature PG from $F$. moniliforme, although they showed a different molecular mass.

\section{DISCUSSION}

Fungal PG has a critical role in the pathogenesis of many plant diseases, but little is known about its structure and function, or the regulation of its synthesis. The difficulty in preparing suitable quantities of homogeneous enzyme is a major problem in this regard. After screening a large number of fungi from our collection, we found a strain of the phytopathogenic fungus $F$. moniliforme (strain FC-10) that produces a large amount of PG (about $10 \mathrm{mg} \mathrm{1}^{-1}$ ) when induced with pectin as a carbon source. It was, therefore, possible to purify several milligrams of 

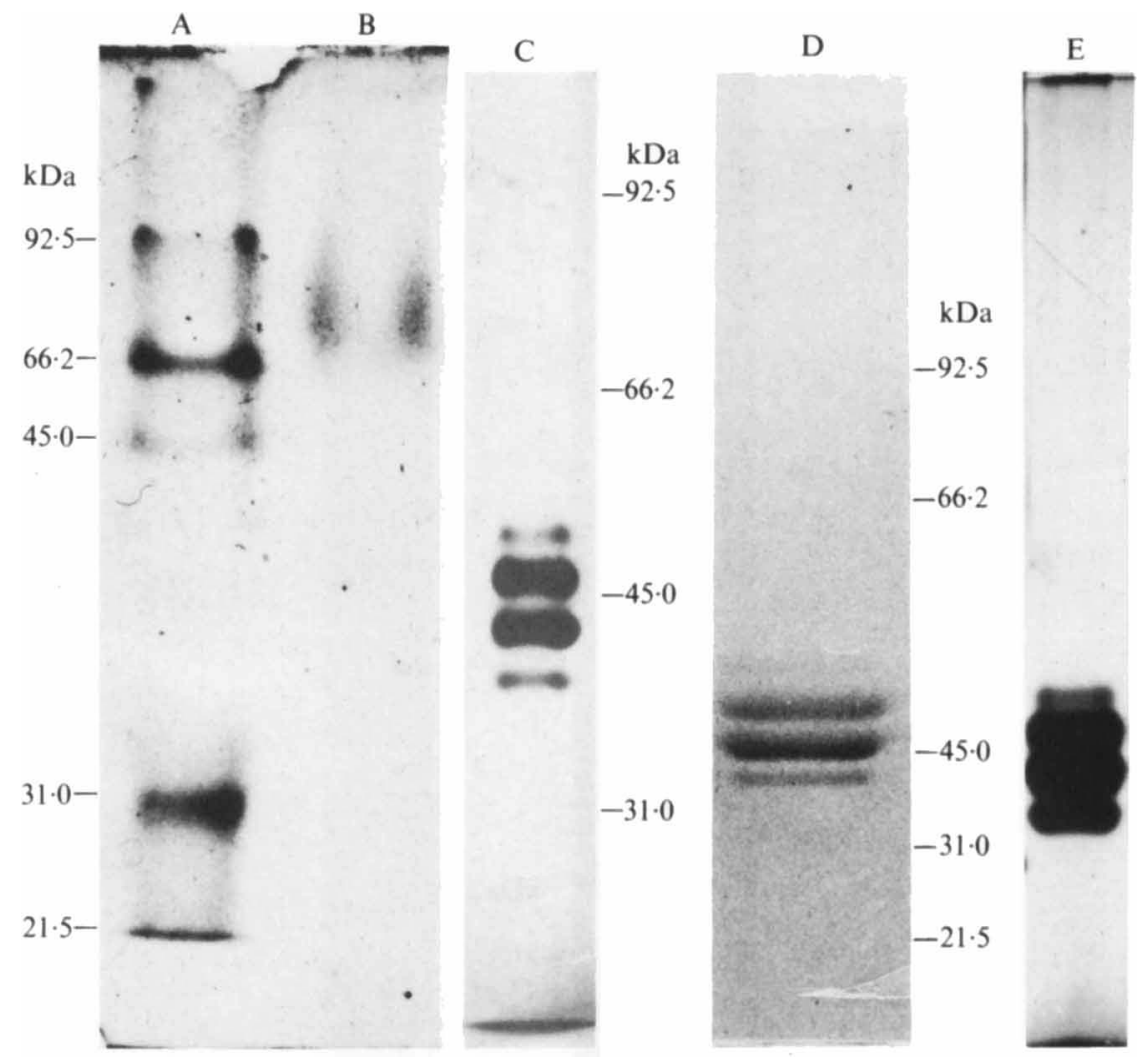

Fig. 6. PAGE of purified PG from $F$. moniliforme in the absence (lane B) and in the presence (lanes $C$ and D) of SDS. Lane A, molecular mass standard proteins stained with Coomassie Blue; B, $10 \mu \mathrm{g}$ PG stained with Coomassie Blue; C, $1 \mu \mathrm{g}$ PG stained with silver nitrate; D, $5 \mu \mathrm{g}$ PG stained with Schiff's reagent; E, $0.5 \mu \mathrm{g}$ PG immunoblotted with $A$. niger IgG.

homogeneous enzyme from a restricted quantity of culture filtrate. Much larger quantities of filtrate were required for purification of comparable amounts of $\mathrm{PG}$ from other fungal sources (Cervone et al., 1977, 1981; Fanelli et al., 1978).

The $F$. moniliforme PG acted as a typical 'endo' enzyme and appeared homogeneous on Sephadex gel filtration, PAGE and isoelectric focusing. However, SDS-PAGE of the apparently homogeneous preparation revealed two major and two minor forms of PG which stained positively for glycoprotein. The native proteins could not be resolved as they neither had a great size difference nor showed a different isoelectric point. The possibility exists that the bands on SDS-PAGE are due to only one or two polypeptide chains with a different kind and/or degree of glycosylation.

Although genes for pectic enzymes have been successfully cloned in phytopathogenic bacteria (Collmer \& Keen, 1986), this goal has not yet been accomplished in fungi. Probably this is due to problems in preparing undamaged and translatable fungal mRNA (Flurkey \& Kolattukudy, 1981). mRNA was isolated from $F$. moniliforme and successfully translated in vitro. Pectininduced mRNA gave two translation products reacting with anti-PG IgG. The translation products had a higher molecular mass than that of mature PG. This is probably due to the fact that, as with most proteins destined for excretion, $P G$ is synthesized as a precursor slightly larger than the mature protein, the leader sequence being removed in post-translational processing (Blobel \& Dobberstein, 1975). 

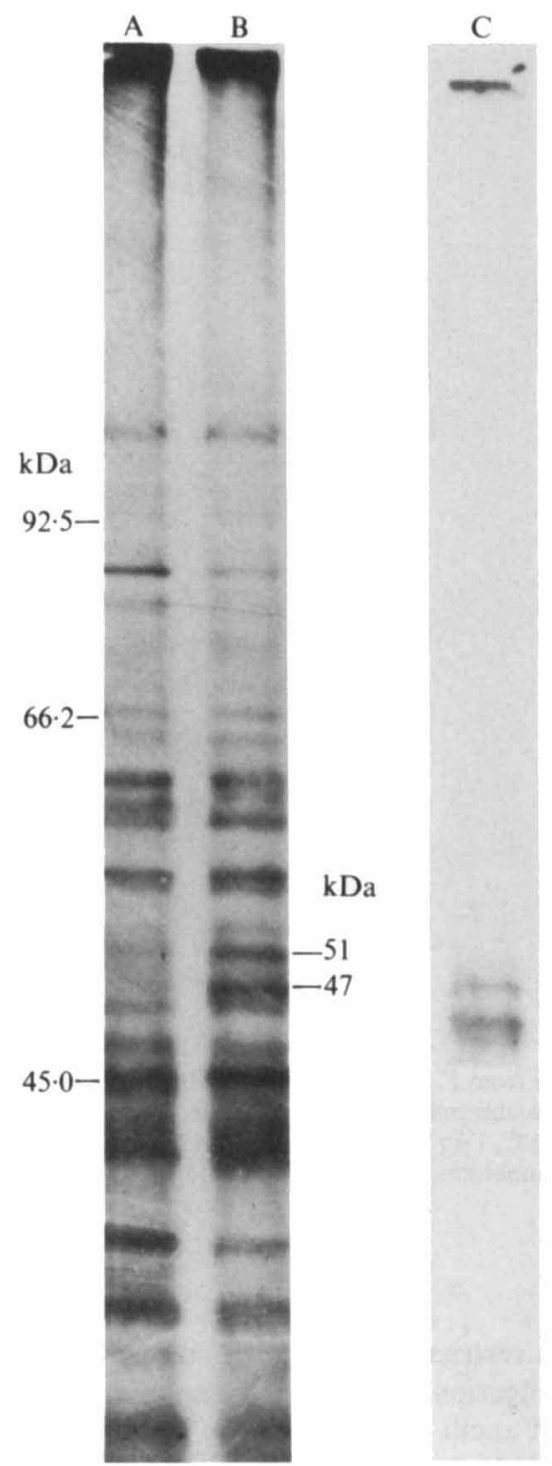

Fig. 7. PAGE of total products of in vitro translated poly(A)-containing mRNA from glucose-grown (lane A) and pectin-grown (lane B) $F$. moniliforme. Lane $C$ was loaded with the inmunoprecipitated in vitro translation products of induced mRNA.

This work was supported by CNR, Italy. Special grant IPRA, subproject 1.

\section{REFERENCES}

ANDREWS, A. T. (1981). Polyacrylamide gel electrophoresis. Homogeneous gel and buffer systems. In Electrophoresis: Theory, Techniques and Biochemical and Clinical Applications, pp. 5-49. Oxford: Clarendon Press.

Bateman, D. F. \& Basham, H. G. (1976). Degradation of the plant cell walls and membranes by microbial enzymes. In Encyclopedia of Plant Physiology, vol. 4, Physiological Plant Pathology, pp. 316-355. Edited by $\mathbf{R}$. Heitefuss \& P. H. Williams. Berlin: SpringerVerlag.
Blobel, G. \& Dobberstein, D. (1975). Transfer of proteins across membranes. I. Presence of proteolytically processed and unprocessed nascent immunoglobulin light chains on membrane-bound ribosomes of murine myeloma. Journal of Cell Biology 67, 835-851.

Bruce, R. J. \& West, C. A. (1982). Elicitation of casbene synthetase activity in castor bean. The role of pectic fragments of the plant cell wall in elicitation by fungal endopolygalacturonase. Plant Physiology 69, 1181-1188. 
Cervone, F. Scala, A., Foresti, M., Cacace, M. G. \& Noviello, C. (1977). Endopolygalacturonase from Rhizoctonia fragarie: purification and characterization of two isoenzymes. Biochimica et biophysica acta 482, 379-385.

Cervone, F., Andebrhan, T., Coutts, R. H. A. \& WoOD, R. K. S. (1981). Effect of French bean tissue and leaf protoplasts on Colletotricum lindemuthianum polygalacturonase. Phytopathologische Zeitscrift 102, 238-246.

Cervone, F., De lorenzo, G., Salvi, G. \& CamarDELLA, L. (1986). Molecular evolution of fungal polygalacturonase. In Biology and Molecular Biology of Plant-Pathogen Interactions, pp. 385-392. Edited by J. Bailey. Berlin: Springer-Verlag.

ChIN, D. J., LuSKeY, K. L., FAust, J. R., MACDonald, R. J., Brown, M. S. \& Goldstein, J. L. (1982). Molecular cloning of 3-hydroxy-3-methylglutaryl coenzyme A reductase and evidence for regulation of its mRNA. Proceedings of the National Academy of Sciences of the United States of America 79, 77047708.

Collmer, A. \& KeEn, N. T. (1986). The role of pectic enzymes in plant pathogenesis. Archives of Phytopathology 24, 383-409.

COOPER, R. M. (1984). The role of cell wall-degrading enzymes in infection and damage. In Plant diseases: Infection, Damage and Loss, pp. 13-27. Edited by R. K. S. Wood \& G. J. Jellis. Oxford: Blackwell Scientific Publcations.

Eveleigh, J. W. \& LeVy, D. E. (1977). Immunochemical characteristics and preparative applications of agarose-based immunoadsorbent. Journal of Solidphase Biochemistry 2, 45-78.

Fanelli, C., Cacace, M. G. \& Cervone F. (1978). Purification and properties of two polygalacturonases from Trichoderma koningii. Journal of General Microbiology 104, 305-309.

FLURKeY, W. H. \& KolatTuKudy, P. E. (1981). In vitro translation of cutinase mRNA : evidence for a precursor form of an extracellular fungal enzyme. Archives of Biochemistry and Biophysics 212, 151-161.

Jones, T. M., ANDERSON, A. J. \& Albersheim, P. (1972). Host pathogen interactions. IV. Studies on the polysaccharide-degrading enzymes secreted by Fusarium oxysporum f. sp. lycopersici. Physiological Plant Pathology 2, 153-166.

KARR, A. L. \& Albersheim, P. (1970). Polysaccharidedegrading enzymes are unable to attack plant cell walls without prior action by a "wall-modifying" enzyme. Plant Physiology 46, 69-80.

KESSLER, S. W. (1981). Use of Protein A-bearing staphylococci for the immune precipitation and the isolation of antigens from cells. Methods in Enzymo$\log y$ 73, 442-460.

MILleR, G. L. (1959). Use of dinitrosalicylic acid reagent for determination of reducing sugar. Analytical Chemistry 31, 425-427.

Nasuno, S. \& StarR, H. P. (1966). Polygalacturonase of Erwinia carotovora. Journal of Biological Chemistry 53, 375-380.

Nelson, N. (1944). A photometric adaptation of the Somogyi method for the determination of glucose. Journal of Biological Chemistry 153, 375-380.

OUCHTERLONY, O. (1962). Diffusion in gel methods for immunological analysis II. Progress in Allergy 61, 36154.

SOMOGYI, M. (1952). Notes on sugar determination. Journal of Biological Chemistry 159, 19-23.

STUDIER, F. W. (1973). Analysis of bacteriophage T7 early RNA's and proteins on slab gels. Journal of Molecular Biology 79, 237-248.

Towbin, M., StaHelin, T. \& Gordon, J. (1979). Electrophoretic transfer of proteins from polyacrylamide gels to nitrocellulose sheets: procedure and some applications. Proceedings of the National Academy of Sciences of the United States of America 76, $4350-4354$.

Walker-Simmons, M., Hadwinger, L. \& Ryan, C. A. (1983). Chitosans and pectic polysaccharides both induce the accumulation of the antifungal phytoalexin pisatin in pea pods and antinutrient proteinase inhibitors in tomato leaves. Biochemical and Biophysical Research Communications 110, 194-199.

Zacharius, R. M., Zell, T. E., MorRison, J. H. \& WoODLOCK, J. J. (1969). Glycoprotein staining following electrophoresis on acrylamide gels. Analytical Biochemistry 30, 148-152. 